\title{
研究論文
}

\section{コナギとイヌホタルイの多発圃場における機械除草法の改良 一株際機械除草法の開発一}

\author{
中井 譲・鳥塚 智 \\ 滋賀県農業技術振興センター
}

Improvement of a Mechanical Weeding Technique in a Paddy Field where a Large Number of Monochoria vaginalis and Schoenoplectus juncoides Emerged : Development of a Mechanical Weeding Technique for Intra-row Spaces

Joe NAkai and Satoshi Toritsuka

Shiga Prefecture Agricultural Technology Promotion Center

\section{1. 緒言}

有機農業は, 農業の自然循環機能を増進し，農 業生産活動に由来する環境への負荷を大幅に低減 するものであり，生物多様性の保全に資するもの である。また，消費者の食料に対する需要が高度 化し，かつ，多様化する中で，安全かつ良質な農 産物に対する消費者の需要に対応した農産物の供 給に資するものである. しかしながら, 現状では, 化学的に合成された肥料および農薬を使用する通 常の農業に比べて, 多くの技術的な課題を抱えて いる(農林水産省 2007)。 また, 有機稲作の技術的 課題の都道府県調查では, 杂隹草防除が最も深刻な 問題になっている (財団法人日本土壤協会 2012). 水稲有機栽培の雑草防除技術についてみると, ア イガモや魚類の放飼による除草技術, マルチ除草 技術，米ぬかなど新鮮有機物の土壤表面処理によ る抑草技術，機械除草技術が実践されている。中 でも，米ぬかなど新鮮有機物の土壌表面処理は, 身近にある資材を使用できる。 さらに，ペレット 状に成形されたものを用いると, 背負式動力散布

平成 24 年 8 月 24 日受付

平成 25 年 5 月 11 日受理

Corresponding author

中井譲 Joe NAKAI

厂521-1301 滋賀県近江八幡市安土町大中 516

516, Dainaka, Azuchi-cho, Omihachiman-shi, Shiga, 521-1301,

Japan

E-mail : nakai-joe@pref.shiga.lg.jp
機や水田用栽培管理ビークルなどの粒状物散布装 置で施用でき，散布作業の省力・軽労化が可能に なる. しかしながら，米ぬか土壤表面処理の抑草 効果は, コナギやイヌホタルイに対して低いこと が明らかにされている（中井・鳥塚 2009 ; 中山 2010 ; 中井ら 2011). したがって, コナギやイヌ ホタルイの埋土種子量の多い水田では，米ぬか土 䗙表面処理を実施しても，雑草が多発する危険性

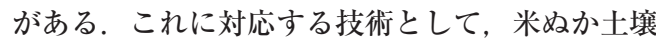
表面処理と機械除草の組み合わせによる複合除草 技術が報告されている（吉田ら 2010 ; 中井ら 2011). また, 近年の除草機の開発動向について みると，条間のみならず株際あるいは株の近傍ま でを機械的に除草する機構が実用化されている (宮原 2007). しかしながら, 滋賀県の事例では, 株際対応除草機の導入は，コスト面から一部の大 規模栽培農家にとどまっている. 小規模栽培農家 は，機械除草を低価格の歩行型水田用中耕除草機 で実施しているが，株際除草対策が課題となって いる. そこで, 本研究では, 歩行型水田用中耕除 草機のロータ配列を除草作業ごとに変更すること で, 株際除草を可能にする作業法（以下,「株際機 械除草」という）を検討した，具体的には，米ぬ か土壌表面処理後にコナギとイヌホタルイが多発 した圃場で，株際機械除草の効果を検討したので 報告する. 


\section{2. 材料および方法}

\section{1）試験区および耕種概要}

本研究は, 滋賀県農業技術振興センター（近江 八幡市安土町大中）の水稲栽培圃場で実施した. また，試験圃場では，2005 年と 2006 年に米ぬか 土壤表面処理による無除草剂水稲栽培を実施した が，コナギとイヌホタルイが残草し，2006 年にイ ヌホタルイが多発した戋場である（表 1$).$

2007 年に実施した本試験では，米ぬか土壤表面 処理区（面積; $248 \mathrm{~m}^{2}$ ) と米奻壤表面処理と 株際機械除草の組み合わせによる複合除草区（面 積; $216 \mathrm{~m}^{2}$, 以下「米ぬか土壤表面処理一株際機 械除草区」という）を設置し，米ぬか土壌表面処 理後の残草に対する株際機械除草の効果を検討し

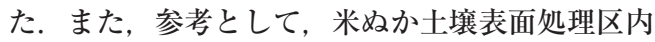
にあぜ波シートで完全に仕切った無除草区（2m $\times 2 \mathrm{~m} ） 2$ 所を設置した。 さらに，米ぬか土㗒表 面処理区と米奻壤表面処理 - 株際機械除草区 には，調査ブロック 3 地点 $(15$ 条 $\times 5 \mathrm{~m})$ を設置 した.

移植（品種；「コシヒカリ」，供試苗 ; 3 4 葉の 中苗）は, 代かき翌日の 5 月 17 日に乗用型田植機 (5 条) を用いて実施した. 米ぬか土壤表面処理は, 移植翌日に背負式動力散布機を用いて，無洗米製
造工程で粒状に整形された米ぬか $150 \mathrm{~kg} / 10 \mathrm{a}$ を 土褰表面に施用した。株際機械除草は， 3 条の歩 行型水田用中耕除草機（以下,「中耕除草機」とい う）を用いて，1 回目を 6 月 7 日（代かき 22 日後) に, 2 回目を 6 月 13 日 (同 28 日後)に実施した(表 2 , 図 1)。施肥は, 移植翌日の米ぬか $150 \mathrm{~kg} / 10 \mathrm{a}$ $\left(\mathrm{N} ; 3.0 \mathrm{~kg} / 10 \mathrm{a}, \mathrm{P}_{2} \mathrm{O}_{5} ; 7.5 \mathrm{~kg} / 10 \mathrm{a}, \mathrm{K}_{2} \mathrm{O} ; 4.5 \mathrm{~kg} / 10 \mathrm{a}\right)$ 施用に加えて, 穂肥として出穂 18 日前に背負式動 力散布機でフェザーミール，なたね油かすおよび 魚かすによって構成された有機質肥料 $43 \mathrm{~kg} / 10 \mathrm{a}$ $\left(\mathrm{N} ; 3.0 \mathrm{~kg} / 10 \mathrm{a}, \mathrm{P}_{2} \mathrm{O}_{5} ; 0.9 \mathrm{~kg} / 10 \mathrm{a}, \mathrm{K}_{2} \mathrm{O} ; 3.0 \mathrm{~kg} / 10 \mathrm{a}\right)$ を施用した。水管理については，移植直後から幼 穂形成期までは, 水深 $7 \mathrm{~cm}$ 以上の深水管理を行 い, 幼穂形成期から出穂 20 日後までは, 水深 3〜 $\mathrm{cm}$ の湛水管理を行い, 出穂 20 日後以降は, 成熟 期まで間断かん水管理を行った.

2）移植作業法および株際機械除草法

(1) 移植作業法

5 条植の乗用型田植機による移植作業は, 隣接 行程間 $35 \mathrm{~cm}$ （1 作業行程 $155 \mathrm{~cm} ）$ に設定するた めに，乗用型田植機のマーカを慣行より $5 \mathrm{~cm}$ 外 側に取り付けて実施した（図 2).

（2）中耕除草機のロータの配置

1 回目には, 中耕除草機の両側のロータを条間

表 1 米奻壤表面処理後の個体数および生体重

\begin{tabular}{clcrrr}
\hline \hline \multicolumn{1}{c}{ 項目 } & 草種名 & \multicolumn{2}{c}{2005 年 } & \multicolumn{2}{c}{2006 年 } \\
\hline 個体数 & コナギ & $93(100)$ & 82 & $(88)$ \\
$\left(\right.$ 個体 $\left./ \mathrm{m}^{2}\right)$ & イヌホタルイ & $72(100)$ & 306 & $(425)$ \\
\hline 生体重 & コナギ & $18(100)$ & 24 & $(133)$ \\
$\left(\mathrm{g} / \mathrm{m}^{2}\right)$ & イヌホタルイ & $15(100)$ & & 215 & $(1,433)$ \\
\hline
\end{tabular}

注 1）移植 (品種；「コシヒカリ」, 供試苗；3４ 葉の中苗）は，代かき翌日（2005 年 ; 5 月 16 日，2006 年； 5 月 17 日）に実施した。

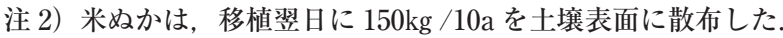

注 3）雑草抜き取り調查は, 2005 年が 7 月 1 日に, 2006 年が 7 月 7 日に実施した.

注 4) 括弧内は, 2005 年の值を 100 としたときの割合を示す.

注 5）コナギ, イヌホタルイ以外の雑草は, 2005 年にマツバイが僅かに発生した.

表 2 試験区の作業経過（2007 年）

\begin{tabular}{|c|c|c|c|c|c|c|}
\hline 試験区 & 代かき & 移植 & 米ぬか処理 & 機械除草(1) & 機械除草(2) & 雑草抜取調查 \\
\hline $8 x_{0}$ & $(0)$ & 5 月 17 日 & 5 月 18 日 $(+2)$ & 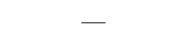 & - & $+48)$ \\
\hline $\begin{array}{l}\text { 米ぬか土壤表面処理一 } \\
\text { 株際機械除区 }\end{array}$ & 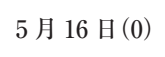 & 5 月 17 日 (+1) & 5 月 18 日 & 6 月 7 日 $(+22)$ & 6 月 13 日 $(+28)$ & 7 月 3 日 $(+48)$ \\
\hline 無除草区 & 5 月 16 日 $(0)$ & 5 月 17 日 $(+1)$ & - & - & - & 7 月 3 日 $(+48)$ \\
\hline
\end{tabular}

注 1）+の後の数字は, 代かき後日数を示す. 


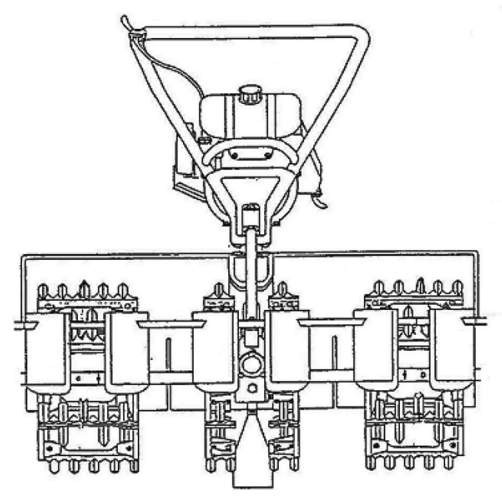

<主要諸元>

\begin{tabular}{|c|c|}
\hline 全長 $\times$ 全幅 $\times$ 全高 $(\mathrm{mm})$ & $1340 \times 840 \times 895$ \\
\hline 質量（kg） & 14. 1 \\
\hline 伝導方式 & 遠心クラッチーウオームギア（減速比 $1 / 35$ ) \\
\hline 作業条数 & 3（条間 $30 \mathrm{~cm}$ ) \\
\hline ロータ幅（cm） & 18. 0 （中央部は $16.0 ）$ \\
\hline ロータ径（cm） & 36 \\
\hline ロータ回転数（rpm） & $120 \sim 180$ \\
\hline 排気量（cc） & 41.5 \\
\hline 出力 (kW) & 1.5 \\
\hline
\end{tabular}

図 1 歩行型水田用中耕除草機の概略図と主要諸元

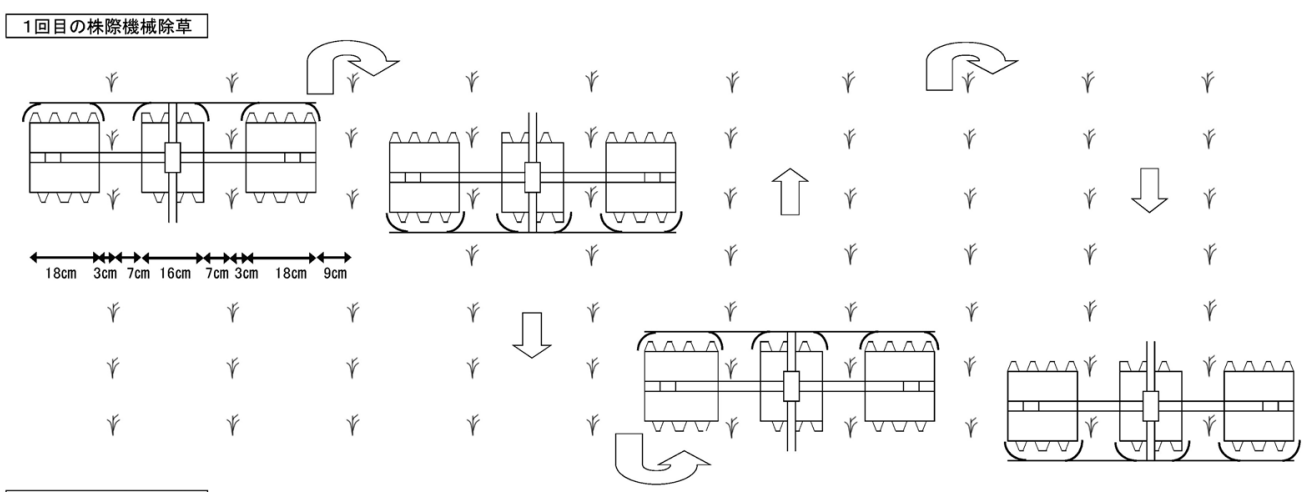

2回目の株際機械除草
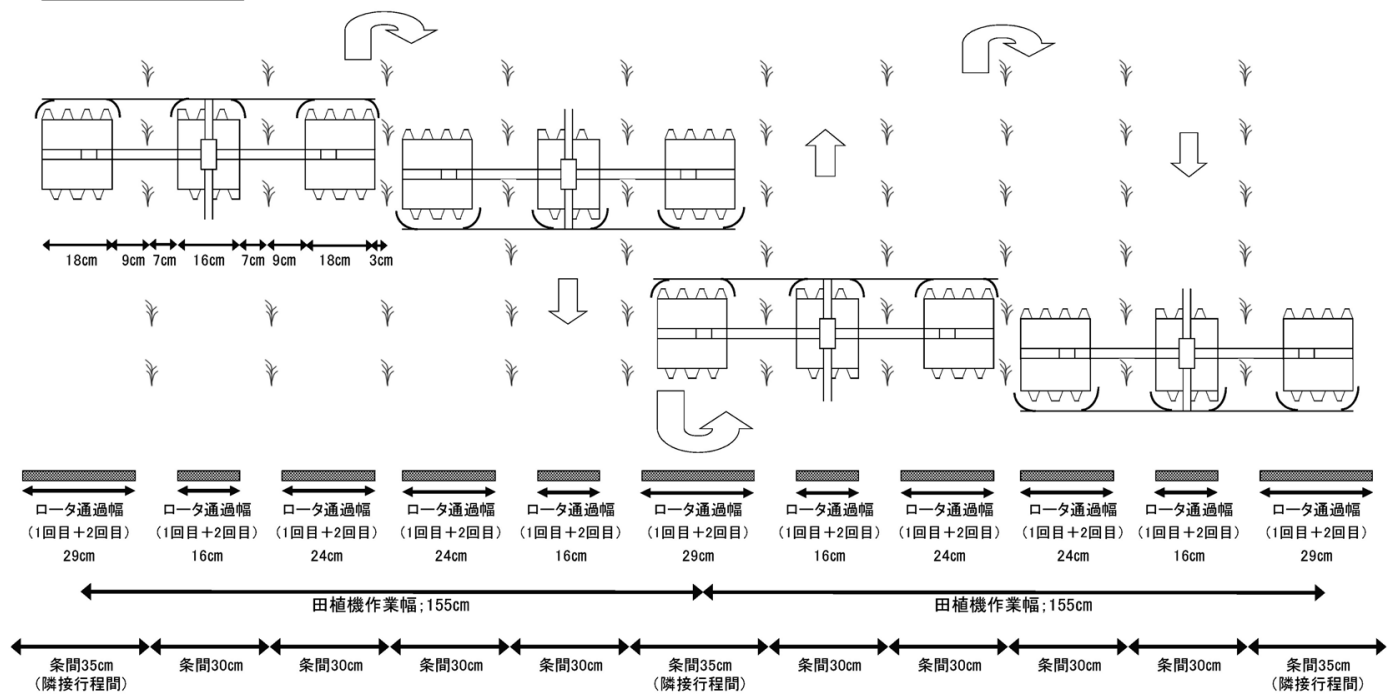

図 2 供試した中耕除草機による株際機械除草法

注 1）ロー夕通過率は, 条間が $92.4 \%$ (田植機 1 行程 $105 \mathrm{~cm}$ のうち $97 \mathrm{~cm}$ 通過), 株際が $24.0 \%$ (田植機 1 行程 $50 \mathrm{~cm}$ の うち $12 \mathrm{~cm}$ 通過), 条間+株際が $70.3 \%$ (田植機 1 行程 $155 \mathrm{~cm}$ のうち $109 \mathrm{~cm}$ ) である.

注 2）条間は稲株間 $30 \mathrm{~cm}$ のうち株際以外の中央部分を示し, 株際は稲株の中心から左右 $5 \mathrm{~cm}$ の部分を示す. 
の中心部から $3 \mathrm{~cm}$ 内側に配置した. 2 回目には, 中耕除草機の両側のロー夕を条間の中心部から $3 \mathrm{~cm}$ 外側に配置した（図 2).

（3）株際機械除草法

株際機械除草については, 1 回目, 2 回目ともに, 1 行程の移植作業につき, 2 行程の除草作業を実 施した。 また, 2 回目の株際機械除草時には, ロー 夕の配列から欠株および損傷株が多発する危険が 高い. そこで, 前述のとおり田植機の隣接行程間 は, 久株および損傷株を防止するため, 慣行の 30 $\mathrm{cm}$ 設定を $35 \mathrm{~cm}$ 設定に広げた。 また，除草作業 時のロー夕通過率は, 条間が $92.4 \%$ （田植機 1 行 程 $105 \mathrm{~cm}$ のうち $97 \mathrm{~cm}$ 通過), 株際が $24.0 \%$ (田植 機 1 行程 $50 \mathrm{~cm}$ のうち $12 \mathrm{~cm}$ 通過), 条間+株際が $70.3 \%$ （田植機 1 行程 $155 \mathrm{~cm}$ のうち $109 \mathrm{~cm}$ ）であ る.な扮, ロー夕通過率は, 1 回目もしくは 2 回 目にロータが通過した地点の割合を示す（図 2).

（4）株際機械除草の実施時期

1 回目 (6月 7 日; 代かき 22 日後) は, コナギ 3〜 4 葉, イヌホタルイ 4 5 葉に実施し, 2 回目 (6月 13 日；同 28 日後）は, コナギ $4 \sim 6$ 葉, イヌホ夕 ルイ 5 葉から花茎抽出期に実施した。

3）調查項目および方法

（1）水稲幼穂形成期の雑草発生状況

米奻壤表面処理区と米ぬか土壤表面処理一 株際機械除草区の雑草抜き取り調查は, 水稲幼穂 形成期に図 3 に示す枠 $(50 \mathrm{~cm} \times 90 \mathrm{~cm} ; 3$ 株/条 $\times$ 3 条 $=9$ 株が入る枠）を用いて, 調查ブロック内 2 地点で実施した，個体数 (個体 $\left./ \mathrm{m}^{2}\right)$ と生体重 $(\mathrm{g} /$ $\mathrm{m}^{2}$ ) は, 条間（稲株間 $30 \mathrm{~cm}$ のうち, 株際以外の 中央部分）および株際（稲株の中心から左右 $5 \mathrm{~cm}$ の部分）ごとに抜き取って，条間，株際および条

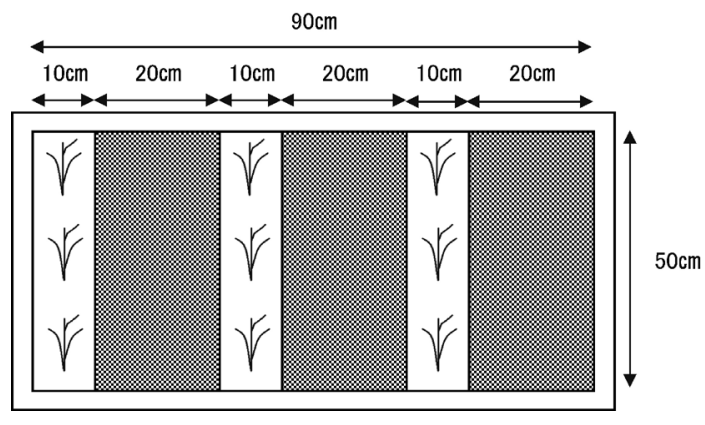

図 3 雑草抜き取り調查枠の概略図 注 1）【の部分は条間を, $\square$ の部分は株際を示す.
間 +株際 (加重平均; $2 / 3 \times$ 条間 $+1 / 3 \times$ 株際) ごと に算出した。また，無除草区 2 力所の雑草抜き取 り調查は, 水稲幼穂形成期に方形枠 $(50 \mathrm{~cm} \times 50$ $\mathrm{cm}$ ）を用いて各 1 地点で害施し, 個体数（個体/ $\left.\mathrm{m}^{2}\right)$ と生体重 $\left(\mathrm{g} / \mathrm{m}^{2}\right)$ を算出した。 なお, 生体重 は, 根部に付着した土を洗い落としてから, 表面 に付着した水分を取り除いて測定した.

(2) 作業時間

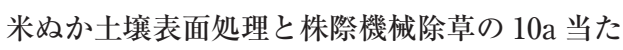
りの作業時間は, 実際の作業に加えて米ぬかや混

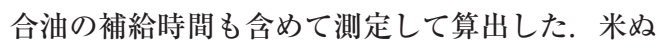
か土壤表面処理は, 固場全面（短辺 $22.5 \mathrm{~m} \times$ 長辺 $80 \mathrm{~m})$ で, 株際機械除草は, 1 回目, 2 回目ともに $864 \mathrm{~m}^{2}$ (短辺 $10.8 \mathrm{~m} \times$ 長辺 $80 \mathrm{~m}$ ) で実施した作業 時間を測定した，なお，各作業ともに作業者は 1 名であった。

（3）水稲収量およびその構成要素

収量調查は, 米奻袞表面処理区と米始少 壤表面処理一株際機械除草区で害施した。精玄米 重は, 調査ブロックごとに稲株 75 株を刈り取っ て, 脱穀, 唐箕選, 粉すりの実施後に $1.8 \mathrm{~mm}$ の穊 で選別して算出した。また, 千粒重は, 精玄米重 の測定サンプルを用いて算出した，なお，精玄米 重と千粒重は, 水分含量 $14.5 \%$ に換算した。穂数, 登熟歩合, 一穂頴花数の調査は, 丸山 (2007) の調 查手順に準じて, 代表株により塞施した。

\section{3. 結果および考察}

1）水稲幼穂形成期の雑草発生状況

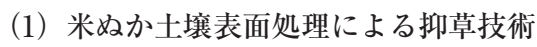

米奻壤表面処理区では, コナギは, 個体数 170 個体 $/ \mathrm{m}^{2}$, 生体重 $53 \mathrm{~g} / \mathrm{m}^{2}$ の発生が見られ, イ ヌホタルイは, 個体数 570 個体 $/ \mathrm{m}^{2}$, 生体重 441 $\mathrm{g} / \mathrm{m}^{2}$ の発生が見られた。また，無除草区と比較 すると, コナギは, 個体数 $30 \%$, 生体重 $12 \%$ であ り, イヌホタルイは, 個体数 $148 \%$, 生体重 $91 \%$ であった，なお，無除草区では，アゼナ類，タマ

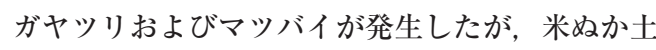
壌表面処理区では, これらの雑草の発生がほとん ど見られなかった（表 3 ).

つまり, 試験围場のように米奻壤表面処理 単独による無除草剂水稲栽培を連年実施し, イヌ ホタルイの埋土種子量が著しく増加した戋場で

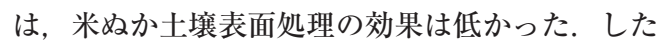
がって, 持続可能性の高い無除草剂水稲栽培を継 
中井・鳥塚：コナギとイヌホタルイの多発围場における機械除草法の改良

表 3 水稲幼穂形成期における米奻壤表面処理区と無除草区の水田雑草の個体数と生体重（2007 年）

\begin{tabular}{|c|c|c|c|c|c|c|c|c|c|c|}
\hline 項目 & 試験区名 & $\begin{array}{l}\text { タイヌ } \\
\text { ビエ }\end{array}$ & アゼナ類 & コナギ & $\begin{array}{c}\text { キカシ } \\
\text { グサ }\end{array}$ & $\begin{array}{c}\begin{array}{c}\text { タマガヤ } \\
\text { ツリ }\end{array} \\
\end{array}$ & $\begin{array}{l}\text { チョウ } \\
\text { ジ夕デ }\end{array}$ & $\begin{array}{l}\text { イヌホ } \\
\text { タルイ }\end{array}$ & $\begin{array}{l}\text { ア゙イ } \\
\text { バイ }\end{array}$ & 合計 \\
\hline \multirow{2}{*}{$\begin{array}{l}\text { 個体数 } \\
\left(\text { 個体 } / \mathrm{m}^{2}\right)\end{array}$} & 米ぬか土土 & 1 & $\begin{array}{ll}0 & (0)\end{array}$ & $170(30)$ & 1 & $1(0.6)$ & 1 & $723(148)$ & - & $897 \quad(62)$ \\
\hline & 無除草区 & 2 & $226(100)$ & $570(100)$ & 0 & $156(100)$ & 0 & $488(100)$ & - & $1442(100)$ \\
\hline \multirow{2}{*}{$\begin{array}{l}\text { 生体重 } \\
\left(\mathrm{g} / \mathrm{m}^{2}\right)\end{array}$} & 米ぬか土 & 2 & $\begin{array}{ll}0 & (0)\end{array}$ & $53(12)$ & $\mathrm{t}$ & $\mathrm{t} \quad(0)$ & $\mathrm{t}$ & $250(91)$ & $1 \quad(5)$ & $306 \quad(40)$ \\
\hline & 無除草区 & $\mathrm{t}$ & $7(100)$ & $441(100)$ & 0 & 13(100) & 0 & $274(100)$ & $22(100)$ & $757(100)$ \\
\hline
\end{tabular}

注 1）括弧内は無除草区を 100 としたときの割合を示す.

注 2）マッバイは地中に根系を伸ばして分株を発生させるため, 生体重のみ表記した。注 3）t は $1 \mathrm{~g}$ 未満を示す.

表 4 水稲幼穂形成期における水田雑草の個体数と生体重（2007 年）

\begin{tabular}{|c|c|c|c|c|c|c|c|c|c|c|c|}
\hline 項目 & 試験区名 & 位置 & $\begin{array}{l}\text { タイヌ } \\
\text { ビエ }\end{array}$ & $\begin{array}{l}\text { アゼ } \\
\text { ナ類 }\end{array}$ & コナギ & $\begin{array}{l}\text { キカシ } \\
\text { グサ }\end{array}$ & $\begin{array}{l}\text { タマガ } \\
\text { ヤツリ }\end{array}$ & $\begin{array}{l}\text { チョウ } \\
\text { ジタデ }\end{array}$ & $\begin{array}{l}\text { イヌホ } \\
\text { タルイ }\end{array}$ & $\begin{array}{l}\text { マッ゙ } \\
\text { バイ }\end{array}$ & 計 \\
\hline \multirow{9}{*}{$\begin{array}{l}\text { 個体数 } \\
\left(\text { 個体 } / \mathrm{m}^{2}\right)\end{array}$} & \multirow{3}{*}{ 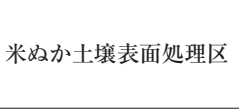 } & 条間 & 1 & 0 & $190(100)$ & 1 & 1 & 1 & $701(100)$ & - & $895(100)$ \\
\hline & & 株際 & 2 & 0 & $129(100)$ & 0 & 2 & 0 & $766(100)$ & - & $900(100)$ \\
\hline & & 条間＋株際 & 1 & 0 & $170(100)$ & 1 & 1 & 1 & $723(100)$ & - & $896(100)$ \\
\hline & \multirow{3}{*}{$\begin{array}{l}\text { 米奻壊表面処理一 } \\
\text { 株際機械草区 }\end{array}$} & 条間 & 0 & 0 & $33(17)$ & 0 & 1 & 0 & $8 \quad(1)$ & - & $42 \quad(5)$ \\
\hline & & 株際 & 2 & 0 & $107(83)$ & 0 & 0 & 0 & $127(17)$ & - & $236(26)$ \\
\hline & & 条間＋株際 & 1 & 0 & $57(34)$ & 0 & 1 & 0 & $47 \quad(7)$ & - & $106(12)$ \\
\hline & \multirow{3}{*}{$\mathrm{t}$ 検定 $(\mathrm{n}=3)$} & 条間 & - & - & $*$ & - & - & - & $*$ & - & $*$ \\
\hline & & 株際 & - & - & ns & - & - & - & $*$ & - & $*$ \\
\hline & & 条間＋株際 & - & - & $*$ & - & - & - & $*$ & - & $*$ \\
\hline \multirow{9}{*}{$\begin{array}{l}\text { 生体重 } \\
\left(\mathrm{g} / \mathrm{m}^{2}\right)\end{array}$} & \multirow{3}{*}{ 米ぬか土壤表面处理区 } & 条間 & 2 & 0 & $59(100)$ & $\mathrm{t}$ & $\mathrm{t}$ & $\mathrm{t}$ & $244(100)$ & 0 & $304(100)$ \\
\hline & & 株際 & 2 & 0 & $41(100)$ & 0 & $\mathrm{t}$ & 0 & $263(100)$ & 2 & $308(100)$ \\
\hline & & 条間+株際 & 2 & 0 & $53(100)$ & $\mathrm{t}$ & $\mathrm{t}$ & $\mathrm{t}$ & $250(100)$ & 1 & $306(100)$ \\
\hline & \multirow{3}{*}{$\begin{array}{l}\text { 米ぬか土壇表面处理一 } \\
\text { 株際機械除草 }\end{array}$} & 条間 & 0 & 0 & $6(10)$ & 0 & $\mathrm{t}$ & 0 & $2 \quad(1)$ & 0 & $7 \quad(2)$ \\
\hline & & 株際 & 7 & 0 & $45(110)$ & 0 & 0 & 0 & $53(20)$ & $\mathrm{t}$ & $106(34)$ \\
\hline & & 条間＋株際 & 2 & 0 & $19(36)$ & 0 & $\mathrm{t}$ & 0 & $19 \quad(8)$ & $\mathrm{t}$ & $40 \quad(13)$ \\
\hline & \multirow{3}{*}{$\mathrm{t}$ 検定 $(\mathrm{n}=3)$} & 条間 & - & - & * & - & - & - & * & - & $*$ \\
\hline & & 株際 & - & - & ns & - & - & - & ns & - & ns \\
\hline & & 条間+株際 & - & - & ns & - & - & - & $*$ & - & $*$ \\
\hline
\end{tabular}

注 1）括弧内は無除草区を 100 としたときの割合を示す.

注 2) $\mathrm{t}$ は $1 \mathrm{~g}$ 未満を示す.

注 3）＊は $5 \%$ 水準で有意なことを, ns は有意でないことを示す

注 4）コナギとイヌホタルイ以外の草種は発生が僅かであったため, 個体数および生体重のみ表記した.

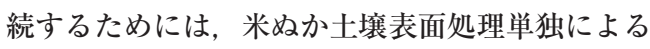
抑草技術では難しいと考えられた。

（2）米奻壤表面処理と株際機械除草の組み合 わせによる複合除草技術

米奻壤表面処理一株際機械除草区の個体数

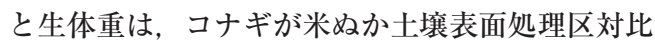
で個体数 $34 \%$, 生体重 $36 \%$ であり, イヌホタルイ が同区対比で個体数 7\%, 生体重 8\%であった.

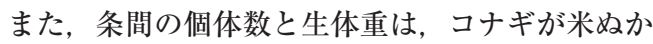
土壤表面処理区対比で個体数 $17 \%$, 生体重 $10 \%$ であり,イヌホタルイが同区対比で個体数 $1 \%$, 生 体重 $2 \%$ であった，株際の個体数と生体重は，コ

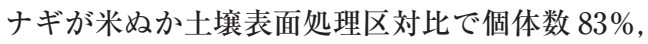
生体重 $110 \%$ であり，イヌホタルイが同区対比で 個体数 $17 \%$, 生体重 $20 \%$ であった（表 4 ）.
以上の結果から, 米ぬか土壤表面処理後にコナ ギおよびイヌホタルイが多発しても，株際機械除 草 2 回を実施することにより, コナギ，イヌホ夕 ルイともに除草効果が得られ, 残草量の大幅な減 少につながることが明らかになった，また，個体 数の滅少率を草種別にみると，コナギは，ロー夕 通過率とほぼ同じ $66 \%$ であったが, イヌホタルイ は, コナギよりかなり高く $93 \%$ であた. さらに, 株際の除草効果をみると, コナギは, 個体数が減 少する傾向が見られたものの, 生体重が減少しな かったが，イヌホタルイは，個体数が減少し，生 体重も減少する傾向が認められた。これらのこと から, 米奻壤表面処理後にコナギとイヌホ夕 ルイの残草が多発した戋場では, 株際機械除草 2 回を実施すると，条間のコナギおよびイヌホタル 
イのみならず，株際のイヌホタルイにも除草効果 が認められ, 残草量の減少に寄与した。

\section{2）作業時間}

米娃壤表面処理の作業時間は, 散布作業と 補給作業をあわせて $0.34 \mathrm{~h} / 10 \mathrm{a}$ であった。 また,

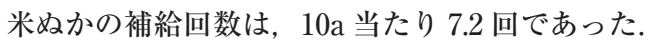
株際機械除草については, 作業時間は, 1 回目が

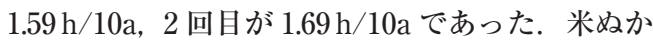
土畩表面処理と株際機械除草 2 回の作業時間は, $3.62 \mathrm{~h} / 10 \mathrm{a}$ であった（表 5)。一方，都府県の慣行 の除草剂水稲栽培では, 除草に要する労働時間は $1.43 \mathrm{~h} / 10 \mathrm{a}$ であった（農林水産省 2012）。本作業 体系は, 作業行程を重複させる必要や米奴補 給時間に時間を要することから，除草に要する時 間は, 慣行と比較して 2.53 倍になった. したがっ て，作業能率を改善するためには，乗用型作業機

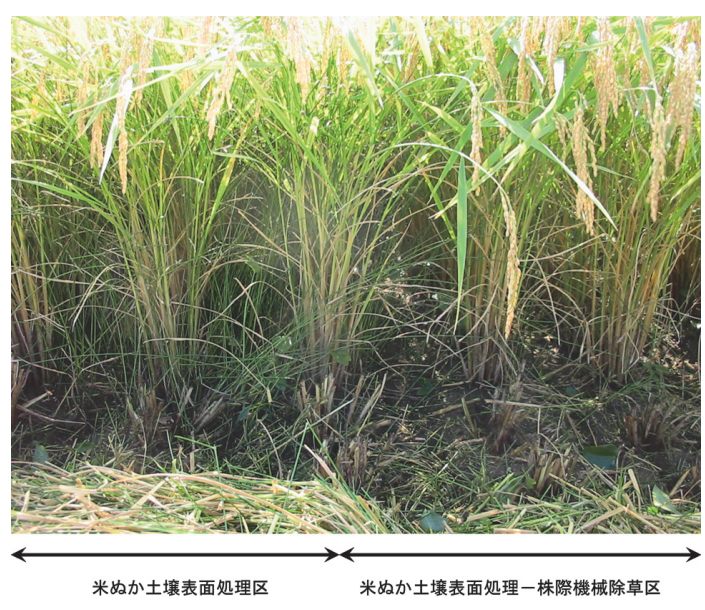

図 4 水稲成熟期の雑草発生状況 (2006 年予備試験)

注 1) 移植（品種；「コシヒカリ」）は, 代かき翌日（5月

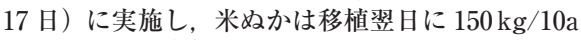
を土壤表面に散布した。

注 2）株際機械除草は， 1 回目が 6 月 7 日（代かき 22 日 後)に, 2 回目が 6 月 13 日(同 28 日後)に実施した.
や米ぬかの補給方法について検討する必要がある と考えられた.

3) 水稲収量およびその構成要素

千坂 (1966) は, コナギ, タイヌビエ, マツバイ の雑草害に関して, 玄米重 $(\mathrm{y})$ と穂数 $(\mathrm{x})$ の関 係を無雑草区に対する比率で表したとき，各点が だいたい $\mathrm{y}=\mathrm{x}$ の線の近くに分布することから， 雑草害による移植水稲の減収に最も強く働いてい る構成要素は穂数であると述べている，本試験で は, 精玄米重は, 米㘦壤表面処理一株際機械 除草区が $529 \mathrm{~g} / \mathrm{m}^{2}$ に対して, 残草の多発した米 ぬか土袞表面処理区が $422 \mathrm{~g} / \mathrm{m}^{2}$ であった。また, 収量構成要素についてみると, 一穂穎花数と登熟

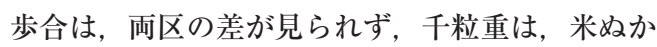
土壤表面処理一株際機械除草区が米妵壤表面 処理区より小さいものの, 精玄米重に対する影響

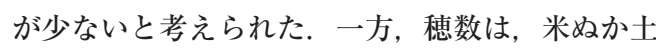
壤表面処理区 263 本 $/ \mathrm{m}^{2}$, 米奻壤表面処理一 株際機械除草区 328 本 $/ \mathrm{m}^{2}$ であったことから, 精 玄米重に強い影響を与えたと考えられた（表 6). 以上のことから, 本試験の米妨土壤表面処理区 では，コナギとイヌホタルイの雑草害が穂数滅に 強く現れて, 収量が著しく減少した。したがって,

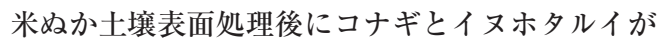
多発した場合, さらに株際機械除草 2 回を行うこ

表 $5 \quad 10 \mathrm{a}$ 当たり作業時間（2007 年）

\begin{tabular}{cc}
\hline \hline 作業名 & $\begin{array}{c}\text { 作業時間 } \\
(\mathrm{h} / 10 \mathrm{a})\end{array}$ \\
\hline 米妨土畩表面処理 & 0.34 \\
株際機械除草 $(1$ 回目 $)$ & 1.59 \\
株際機械除草 $(2$ 回目 $)$ & 1.69 \\
\hline 合 計 & 3.62 \\
\hline
\end{tabular}

注 1）作業時間には，米ぬかと混合油の補給時間 も含む.

表 6 水稲収量およびその構成要素（2007 年）

\begin{tabular}{lcccccc}
\hline \hline \multicolumn{1}{c}{ 試験区 } & $\begin{array}{c}\text { 精玄米重 } \\
\left(\mathrm{g} / \mathrm{m}^{2}\right)\end{array}$ & $\begin{array}{c}\text { 穂数 } \\
\left(\text { 本 } / \mathrm{m}^{2}\right)\end{array}$ & $\begin{array}{c}\text { 一穂頴花数 } \\
(\text { 粒 } / \text { 本 })\end{array}$ & $\begin{array}{c}\text { 総籾数 } \\
\left(100 \text { 粒 } / \mathrm{m}^{2}\right)\end{array}$ & $\begin{array}{c}\text { 登熟歩合 } \\
(\%)\end{array}$ & $\begin{array}{c}\text { 千粒重 } \\
(\mathrm{g} / 1000 \text { 粒 })\end{array}$ \\
\hline 米ぬか土壤表面処理区 & 422 & 263 & 84 & 220 & 88.3 & 21.8 \\
米ぬか土土壤表面処理一株際機械除草区 & 529 & 328 & 90 & 296 & 85.6 & 20.9 \\
\hline $\mathrm{t}$ 検定 $(\mathrm{n}=3)$ & $* *$ & $*$ & $\mathrm{~ns}$ & $* *$ & $\mathrm{~ns}$ & $*$ \\
\hline
\end{tabular}

注 1) 登熟歩合は, 逆正弦変換值で $\mathrm{t}$ 検定を行った.

注 2）**は $1 \%$ 水準で有意なことを， * は $5 \%$ 水準で有意なことを，ns は有意でないことを示す. 
とにより，残草が少なくなり，穂数減による減収 が軽減されることが明らかになった。

\section{4. 摘要}

米ぬか土壇表面処理単独による水田雑草の抑草 技術は，コナギとイヌホタルイに対する抑草効果

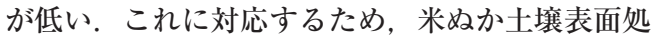
理後に，歩行型水田用中耕除草機のロー夕の配列 変更による株際機械除草技術を検討した。

米ぬか土壤表面処理後にコナギとイヌホタルイ の残草が多発した围場では，歩行型水田用中耕除 草機で株際機械除草 2 回を実施することにより, 条間のコナギとイヌホタルイのみならず，株際の イヌホタルイにも除草効果が認められた。また, 米㘦㗒表面処理と株際機械除草 2 回を組み合 わせた複合除草技術は，米奻壤表面処理単独 と比較して, 雑草害による水稲収量の減少を軽減 することができた.

\section{謝辞}

本論文の作成に当たっては，神戸大学大学院農 学研究科の伊藤一幸博士，川村恒夫博士，庄司浩 一博士に貴重な助言をいただきました。記して謝 意を表します。また，戋場試験の実施に当たって は, 滋賀県農業技術振興センターの三謧清道氏, 吉岡善明氏，渡邊敏之氏，前田武彦氏に協力をい ただきました，記して謝意を表します。

$$
\text { キーワード }
$$

イヌホタルイ，株際機械除草，コナギ，米ぬか土 㙵表面処理，水稲収量

\section{引用文献}

千坂英雄（1966）：水稲と雑草の競争, 雑草研究 $5 ; 16-22$.

丸山幸夫 (2007)：作物の形態調査法：マクロから ミクロまで＼cjkstart収量および収量構成要素，日作 紀 76；601-603.

宮原佳彦 (2007)：機械除草技術開発の動向，東北 の雑草 $7 ; 1-6$.

中井 譲・鳥塚 智 (2009): 米㘦壤表面処理 による水田雑草の抑草効果, 雑草研究 54 ; 233-238.

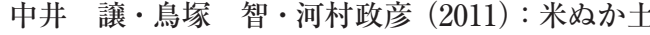
壤表面処理と機械除草の組み合わせによる無 除草剂水稲栽培技術, 雑草研究 $56 ； 242-247$. 中山幸則 (2010) : 米奴水田雑草防除への利用 について，農業および園芸 $85 ； 252-257$.

農林水産省 (2007) : 有機農業の推進に関する基本 的な方針, http://www.maff.go.jp/j/seisan/ kankyo/yuuki/pdf/d-2.pdf（2007 年 4 月 27 日公表)

農林水产省 (2012)：平成 22 年産米及び麦類の生 産費, http : //www.e-stat.go.jp/SG1/estat/ List.do?lid $=000001087471(2012$ 年 3 月 16 日 公表).

財団法人日本土壤協会（2012）：(有機栽培技術の 手引(水稲・大豆等編 $)), I I$. 有機農産物の生 産実態と有機栽培の技術的課題, 東京, pp. 3-6.

\section{Summary}

Rice bran treatment of soil surfaces in paddy fields does not adequately control two weeds, Monochoria vaginalis (Pontederiaceae) and Schoenoplectus juncoides (Cyperaceae). After changing the arrangement of the rotor in a walking cultivator, we examined the effect of weeding the intra-row spaces on the control of weeds in combination with rice bran treatment. In rice paddy fields where many of these residual weeds emerged after rice bran treatment, weeding the intra-row spaces twice reduced not only $M$. vaginalis and $S$. juncoides in the row spaces but also S. juncoides in the intra-row space. Compared to the weedsuppressive technique of rice bran treatment alone, the combination of rice bran treatment and weeding the intra-row space twice preserved paddy rice yields by more effectively controlling weeds.

\section{Key Words}

mechanical weeding technique intra-row spaces, Monochoria vaginalis (Pontederiaceae), paddy rice yields, rice bran treatment of soil surfaces, Schoenoplectus juncoides (Cyperaceae) 